\title{
A magyarországi gyümölcs- és zöldségfeldolgozás területi vizsgálato számviteli mutatók segítségével
}

\section{Kormos Zoltán,}

a Központi Statisztikai Hivatal vezető tanácsosa

E-mail: Zoltan.Kormos@ksh.hu

\section{Harsánụi Gergely,}

a Budapesti Gazdasági Egyetem föiskolai docense, az MTA-BGE Makrogazdasági Fenntarthatósági Kutatócsoport tudományos munkatársa ${ }^{1}$

E-mail:

harsanyi.gergely@uni-bge.hu

\section{Veress Attilo,}

a Budapesti Gazdasági Egyetem egyetemi docense

E-mail: veress.attila@uni-bge.hu
A szerzők számviteli mutatók segítségével tesznek kísérletet a magyarországi területi egységek versenyképességi rangsorának megállapítására a gyümölcs- és zöldségfeldolgozásban. A vizsgálat további célja annak kimutatása, hogy a gyümölcs- és zöldségfeldolgozás során nagyobb termelési értéket előállító területi egységek jobb vagyoni és pénzügyi helyzetben vannak-e, valamint jövedelmezőbbek és hatékonyabbak, ezáltal versenyképesebbek-e, mint társaik.

A tanulmány az SBS-adatbázis (structural business statistics - gazdaságszerkezeti statisztika) sokrétü felhasználhatóságának bemutatására is törekszik, amely adatbázis megbízható forrása a versenyképességi számításoknak. A felállított sorrendek, a vállalati döntéstámogatás mellett, alkalmasak területfejlesztési stratégiák kialakítására és formálására is.

\section{TÁRGYSZÓ:}

Gyümölcs-, zöldségfeldolgozás, -tartósítás.

Versenyképesség.

Számviteli mutatók.

DOI: $10.20311 /$ stat2018.06.hu0593

${ }^{1}$ A cikk az MTA (Magyar Tudományos Akadémia), a BGE (Budapesti Gazdasági Egyetem) Makrogazdasági Fenntarthatósági Kutatócsoport és az MTA Támogatott Kutatócsoportok Irodája keretében és támogatásával készült, melynek félállású alkalmazottja Harsányi Gergely.

A szerzők köszönetüket fejezik ki Szilágyi Dánielnek és Gerse Józsefnek a térképek elkészítésért. 
$\mathrm{A}_{\mathrm{z}}$ élelmiszeripari vállalkozások fokozódó hazai és nemzetközi versenye miatt szükségessé vált müködésük hatékonyságának mérése. A gyümölcs-, zöldségfeldolgozás, -tartósítás kiemelt ágazat, amelynek jelentőségét elsősorban nem az élelmiszeripari termelésen belüli aránya (8,7 százalék volt 2016-ban), hanem a hazai mezőgazdasági alapanyagok felhasználása és a vidéki lakosság foglalkoztatásában, valamint helyben tartásában játszott szerepe adja.

Ezért megfelelő információkkal kell rendelkeznünk az alágazat gazdasági pozíciójáról és versenyképességéről a gazdaságpolitikai célok kitűzéséhez (például pályázati programok kírásához). Tanulmányunk a magyarországi gyümölcs-, zöldségfeldolgozás, -tartósítás alágazatban tevékenykedő vállalkozások területi alapon összesített, 2008 és 2015 közötti évekre vonatkozó adatai alapján, klasszikus számviteli mutatószámok rendszerbe foglalásával törekszik a megyék és a főváros versenyképességi rangsorának felállítására.

Mindezek előtt a szakirodalomban fellelhető, a versenyképesség számviteli szempontból is értelmezhető definícióit és elméleti megközelítéseit tekintjük át.

\section{A versenyképesség elméleti megközelítése és mérési lehetőségei}

A versenyképesség fogalmának meghatározása több évtizede foglalkoztatja a közgazdászokat. A vállalati versenyképesség definiálása körüli kérdések sem tekinthetők lezártnak, annak ellenére, hogy kevesebb szakirodalmi vitát váltottak ki, mint a nemzetgazdasági versenyképességé.

A következőkben - a tanulmány célját szem elött tartva - azon elméleti megközelítéseket foglaltuk az 1. táblázatba, amelyek számviteli szempontból is értelmezik a versenyképességet.

A hivatkozott elméleti kutatók, valamint a gazdaságpolitikusok egyaránt a termelékenységet tekintik a versenyképesség fö ismérvének, függetlenül a vizsgálat alanyának szintjétöl. Némethné ([2009] 138. old.) felhívja a figyelmet, hogy „,a termelés a vállalatokon belül zajlik, vagyis a termelékenység mikroszinten meghatározott és elsődlegesen mikroszinten mérhető kategória, amelyből különféle aggregációk útján képezhetők mezo- vagy makroszintü adatok. Ez utóbbiak az ágazat, régió vagy ország versenyképességének jellemzése mellett alkalmasak a vállalatok, vállalatcsoportok termelékenységének, és ezen keresztül versenyhelyzetének értékelésére. Ezért a 
termelékenységi adatok összehasonlítása alkalmas módszere lehet a versenyképesség jellemzésének."

1. táblázat

\begin{tabular}{|c|c|}
\hline A versenyképességi definíció megfogalmazója & A versenyképesség jelentése/fő ismérve \\
\hline Porter [1980], [1990] & $\begin{array}{l}\text { Magas és növekvő termelékenység, illetve } \\
\text { a nemzetközi versenyben való sikeres helytállás }\end{array}$ \\
\hline Krugman [1996] & Kiemelkedő termelékenység \\
\hline $\operatorname{Cox}[1997]$ & $\begin{array}{l}\text { A bevételek és a ráfordítások közötti különbség maximalizálásá- } \\
\text { nak képessége }\end{array}$ \\
\hline Traill-Pitts [1998] & A profit elérésének és a piaci részesedés növelésének képessége \\
\hline Findrik-Szilárd [2000] & Profit és piaci részesedés \\
\hline Módos [2004] & $\begin{array}{l}\text { A rendelkezésre álló erőforrások felhasználásának és a termé- } \\
\text { kek/szolgáltatások értékesítésének hatékonysága }\end{array}$ \\
\hline Molnár [2006] & Hosszú távú jövedelmező értékteremtés \\
\hline Czakó-Chikán [2007] & $\begin{array}{l}\text { A nyereséges müködés és a termékek/szolgáltatások preferálása a } \\
\text { vásárlók által }\end{array}$ \\
\hline$I M D[2008]$ & $\begin{array}{l}\text { A vállalatok növekvő értéktermelése és ezáltal a lakosság jólété- } \\
\text { nek gyarapodása }\end{array}$ \\
\hline Hüttl [2012] & Kedvezően alakuló termelékenység \\
\hline Európai Bizottság [2014] & $\begin{array}{l}\text { A nemzetközi piacokon értékesíthető javak és szolgáltatások } \\
\text { előállítása magas és fenntartható jövedelmek mellett }\end{array}$ \\
\hline
\end{tabular}

A versenyképesség bemutatott megközelítései alapján mi is elsősorban a termelékenységből indulunk ki, de vizsgálataink során egyéb számszerüsíthető tényezőket is igyekszünk figyelembe venni.

A versenyképesség mérése rendkívül összetett probléma, melyről a témát kutatók véleménye jelentősen eltér. A versenyképesség számszerüsítését célul kitüző szakirodalom ennek megfelelően rendkívül gazdag, a kidolgozott módszerek sokrétüek.

„A versenyképességet általában a győztesek - adottságainak vagy kifejlesztett képességeiknek - számbavétele és elemzése útján lehet meghatározni" (Szilágyi [2008] 6. old.), amelyhez rendkívül nagy számban lelhetök fel a szakirodalomban mutatószámok és indikátorok. Azonban „mindenféle összehasonlítás tartalma, eredménye, értelmezése és információs ereje nagymértékben függ a kiválasztott mutatószámoktól." (Szilágyi [2008] 8. old.)

„A versenyképesség javulását vagy romlását eredményoldalról (ex post) a piaci teljesítményt és a jövedelmezőséget jellemző mutatószámok alakulásával lehet mérni." (Némethné [2010] 188. old.) Ennek megfelelően a legtöbb iparágra készültek 
termelékenységi számítások (például egységnyi munkaórára jutó reálkibocsátás vagy hozzáadott érték) (Hüttl [2012]).

Chikán [2006] vállalati versenyképességi indexének is egyik pillérét a jövedelmezőséget mérő mutatók alkotják, viszonyítási alapjuk pedig az iparági átlag.

A Magyar Nemzeti Bank 2017-es versenyképességi jelentésének a nemzetgazdasági versenyképesség struktúráját, alapjait és célját megjelenítő ábráján is a magas termelékenység a tartós felzárkózás és életszínvonal-növekedés, vagyis a versenyképesség céljának feltétele.

1. ábra. A nemzetgazdasági versenyképesség struktúrája

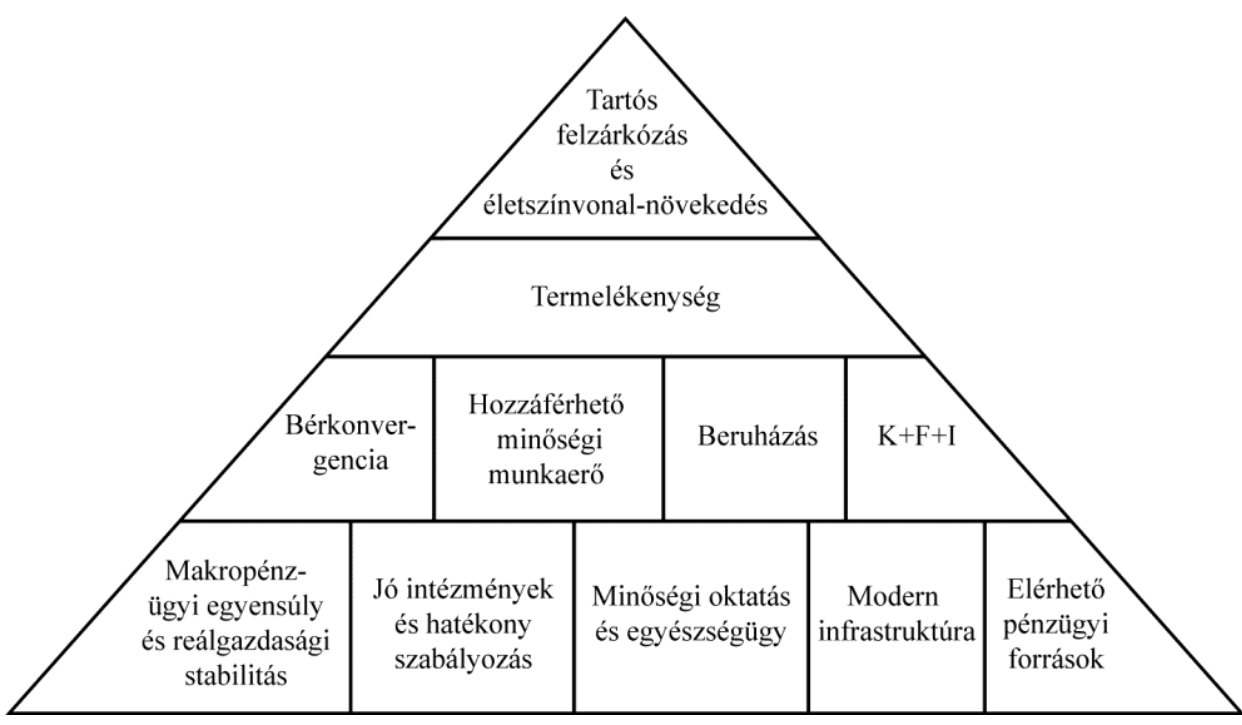

Forrás: $M N B$ [2017].

Megítélésünk szerint mindezek értelmében a versenyképesség ágazati és területi szempontokat egyszerre figyelembe vevő mérésére az erőforrás- és költségelemzések (kínálati versenyképesség) eszközrendszerébe tartozó számvitel kiválóan alkalmas. Analitikus vizsgálatunk az eredményekre koncentráló ún. ex post megközelítések közé tartozik, ahol a „mérhetőség” eleve adott.

Nemzetközi vizsgálatoknál tekintetbe kell venni, hogy „,az egyes vagyontárgyak értékelésével kapcsolatos számviteli szabályozás alapvetően meghatározza a beszámolóból nyerhető információk hasznosíthatóságát" (Harsányi-Siklósi-Veress [2013] 559. old.), ezért az értékelési szabályok különbözhetnek. Jelen tanulmányunkban országon belüli vizsgálatot végzünk, ezért ez a probléma nem áll fenn.

A számviteli információs rendszerekből származó egyszerübb és komplex mutatókon kívül léteznek egyéb, a pénzügyi teljesítményen túli tényezőket is figyelembe vevő 
mutatórendszerek, mint például a „kiegyensúlyozott mutatószámrendszer” (balanced scorecard), amely egyensúlyt kíván teremteni a pénzügyi és nem pénzügyi eredmények között. Tanulmányunkban azonban kizárólag számszerüsíthető pénzügyi-számviteli eredményeket vizsgálunk az SBS-adatbázisra támaszkodva, így a kutatók által gyakran alkalmazott kérdőíves felmérésekből nyerhető nem pénzügyi természetü információk (például az üzleti hangulat indexe) nem képezik elemzésünk tárgyát.

A rendkívül gazdag és hosszú múltra visszatekintő szakirodalommal rendelkező külkereskedelmi versenyképességi vizsgálatokat sem érintjük, mivel a külkereskedelmi statisztikai adatbázisok és a teljesítménystatisztikai adatbázisok összhangja máig nem valósult meg teljes mértékben sem itthon, sem külföldön. Így párhuzamos, esetleg összehasonlító elemzések készítése e két területen nem célravezető.

Jól mérhető, kvantitatív mutatókat a vállalati, nemzeti vagy nemzetközi statisztikákban fellelhetö, ún. kemény adatokból (hard data) számíthatunk. Elemzésünk során az SBS és a nemzeti számlák közös adatbázisából építkeztünk. Ezen közös adatbázis forrása a KSH (Központi Statisztikai Hivatal) éves gazdaságstatisztikai jelentése, valamint a Nemzeti Adó- és Vámhivatalhoz beérkezett adóbevallások. Sajnos meg kellett elégednünk a vállalkozások székhely szerinti adataival, mivel telephelyenkénti bontásban nem állnak rendelkezésre ilyen információk.

\section{A számításokhoz kiválasztott mutatók}

Vizsgálataink során a magyarországi megyék és a föváros gyümölcs-, zöldségfeldolgozás, -tartósítás alágazatát igyekeztünk sorba rendezni vagyoni és pénzügyi, jövedelmezőségi és hatékonysági, illetve együttesen versenyképességi szempontból. Ehhez kerestünk megfelelő mutatókat, amelyek kiválasztása során figyelembe kellett venni, hogy „a beszámolóból számos mutató készíthető, azonban mindegyik másmás aspektusban fejezi ki a vállalkozás gazdálkodásának valamely tulajdonságát" (Kadlecsik [2013] 1074. old.).

A kiválasztást követően vigyázni kell egy-egy mutató értékelésével, ugyanis félrevezetheti az elemzőt, ha nem komplexitásában vizsgálja az adott vállalat/vállalatcsoport/ágazat müködését. Hiszen a mutatóértékek esetleges ingadozásának, jelentős változásának hátterében nemcsak gazdálkodási, hanem például szervezeti- vagy adóváltozások is állhatnak. Ezt a problémát enyhítheti a több év gazdálkodási eredményeiből képzett átlagmutatók felhasználása az elemzés során, valamint a kiszámított mutatóknak nem csupán a bázishoz viszonyított, hanem az alágazati átlaggal vagy az alágazat legjobbjával összevetett értéke is. 
Egy alágazat versenyképességét a szakirodalomból hivatkozott termelékenységen túl vállalkozásai gazdálkodásának stabilitása is döntően befolyásolja. Ennek megfelelően a számviteli mutatókkal megragadható tényezők közül a versenyképesség vizsgálatához a termelékenységet számszerüsítő jövedelmezőségi és hatékonysági mutatókon kívül a vagyoni és pénzügyi helyzetet leíró mutatók is szükségesek. A versenyképesség mérésére összeállított mutatórendszer elemeit a Függelék tartalmazza.

Vizsgálatunk során körültekintően kellett eljárnunk, ugyanis a túl sok és a túl kevés mutató is félrevezető lehet. Mérlegelnünk kellett azt a szempontot, hogy „minél több a mutató, annál finomabb az elemzés, illetve, hogy a mutatók számának egyszerủ növelése kisebb vagy nagyobb mértékben, de mindig növeli az összehasonlítás minőségét, pontosságát vagy információs erejét. Ez többnyire így is van, de nem ritka az olyan eset, amikor a mutatók számának különösebb megfontolás nélküli szaporítása redundanciához vezet, így árt az összehasonlítás minőségének. Ez utóbbi a változók közötti erős korreláció esetén áll elő. Egy másik, gyakran hangoztatott ... elv a változók sokfélesége, az tehát, hogy az indikátorok minél több oldalról jellemezzék a vizsgált jelenséget, esetünkben a versenyképességet, annak minél több eleme legyen képviselve..." (Szilágyi [2008] 9. old.)

\section{A versenyképességi mutatórendszer eredményeiből levonható következtetések}

Számításaink során az azonos megyében székhellyel rendelkező, statisztikai fötevékenység szerint a gyümölcs-, zöldségfeldolgozást, -tartósítást végző vállalkozásokat egy „üzemgazdaságnak” tekintettük. Ezen gazdálkodóegységek adatait aggregáltan kezeltük, vagyis a vállalkozások alapadatainak területi egységenkénti összegzése után (vállalkozásonként nem) számítottunk mutatókat. Így a nagyobb vállalkozásokat (például adózás előtti eredmény szempontjából) gazdasági potenciáljuknak megfelelően nagyobb súllyal tudtuk figyelembe venni.

A kapott eredmények értékeléséhez elsőként érdemes szemügyre vennünk a gyümölcs-, zöldségfeldolgozás, -tartósítás alágazat területi egységenkénti termelési teljesítményét, amelynek 2015-ös értékeit és részesedését az alágazat élelmiszeripari termeléséböl, valamint a vállalkozások számát a 2. táblázatban foglaltuk össze. Ebben az évben az adatbázisban 544 vállalkozás adatai szerepeltek, ezek 65 százaléka 0-4 fő közötti, 28 százaléka 5-49, 7 százaléka pedig 50 fő feletti alkalmazotti létszámmal müködött. Országosan 232 milliárd forint termelési értéket állítottak elö, amelynek 79 százalékát Pest, Bács-Kiskun, Szabolcs-Szatmár-Bereg és Hajdú-Bihar 
megye teljesítménye adta, miközben nyolc megye külön-külön még az 1 százalékot sem érte el.

\section{2. táblázat}

A gyümölcs-, zöldségfeldolgozás, -tartósitás alágazat vállalkozásainak száma, termelési értéke és az élelmiszeripari termelésböl való részesedése területi egységenként, 2015

\begin{tabular}{|c|c|c|c|}
\hline Megye, főváros & $\begin{array}{l}\text { Vállalkozások száma } \\
\qquad(\mathrm{db})\end{array}$ & $\begin{array}{l}\text { Termelési érték } \\
\text { (millió forint) }\end{array}$ & $\begin{array}{l}\text { A területi egység termelésé- } \\
\text { nek aránya az élelmiszeripari } \\
\text { ágazaton belül }(\%)\end{array}$ \\
\hline Bács-Kiskun & 52 & 48597 & 11,6 \\
\hline Baranya & 15 & 8310 & 5,1 \\
\hline Békés & 14 & 1829 & 2,1 \\
\hline Borsod-Abaúj-Zemplén & 13 & 252 & 0,2 \\
\hline Budapest & 56 & 4469 & 0,7 \\
\hline Csongrád & 27 & 3539 & 1,4 \\
\hline Fejér & 9 & 7716 & 4,3 \\
\hline Győr-Moson-Sopron & 20 & 3026 & 2,1 \\
\hline Hajdú-Bihar & 42 & 35903 & 19,4 \\
\hline Heves & 9 & 3979 & 8,9 \\
\hline Jász-Nagykun-Szolnok & 11 & 7444 & 8,8 \\
\hline Komárom-Esztergom & 4 & 727 & 0,5 \\
\hline Nógrád & 8 & 5008 & 59,6 \\
\hline Pest & 131 & 61427 & 15,3 \\
\hline Somogy & 10 & 787 & 0,8 \\
\hline Szabolcs-Szatmár-Bereg & 93 & 38239 & 24,7 \\
\hline Tolna & 8 & 93 & 0,2 \\
\hline Vas & 5 & 16 & 0,0 \\
\hline Veszprém & 10 & 64 & 0,1 \\
\hline Zala & 7 & 923 & 1,8 \\
\hline Ország összesen & 544 & 232349 & 7,0 \\
\hline
\end{tabular}

Forrás: Itt és a további táblázatok, ábrák esetén saját szerkesztés az SBS-adatbázis alapján.

Az évenként kiszámított mutatók többsége esetében hektikus változásokat tapasztaltunk, mind területi egységenkénti értékük, mind a megyék szerinti rangsoruk tekintetében. Egyes mutatók adott évi értékei közelebb álltak egymáshoz, illetve évröl évre csak kisebb mértékben változtak, míg másoknál nagyobbak voltak az adott évi különbségek, és időben is jelentősebben változott az értékük.

A mutatóértékek ingadozásának, jelentős változásának elsősorban a gyümölcs-, zöldségfeldolgozás, -tartósítás alágazat nagyfokú függősége a mezőgazdasági terme- 
lés eredményességétől (adott évi termés mennyiségétől és az attól nagyban függő alapanyagbeszerzési-áraktól, illetve feldolgozóipari munkaerőköltségtől) lehet az oka. Az alágazat vállalkozásainak kiszámíthatóbb működéséhez egyenletes mennyiségü és megbízható minőségű hazai gyümölcsre és zöldségre lenne szükség, mivel döntően Magyarországról származó alapanyagokat használnak fel. A gyümölcs- és zöldségtermesztés pedig különösen kiszolgáltatott az időjárási és piaci körülményeknek. Erre lehet következtetni az anyagjellegü ráfordítások értékének évenkénti jelentős eltéréséből is.

Ezért az évenként hektikusan változó mutatóértékek helyett a vizsgált nyolc év átlagára számítottuk ki az egyes évek alapadatainak összegzése után a kiválasztott számviteli mutatókat területi egységenként. A folyó áras alapadatok évenkénti átárazását nem végeztük el, mivel alágazati árindexek nem álltak rendelkezésünkre. Ezt az eljárást alkalmaztuk valamennyi kiválasztott mutató esetében.

Ezt követően az alágazat adott területi egységhez tartozó vállalkozásainak ismertetett módon kiszámított számviteli mutatók értékét az adott mutató maximális értékéhez viszonyítottuk, annak érdekében, hogy azok egymással összevethetők legyenek. Az így kapott százalékos eredményeket területi egységek szerint foglaltuk össze a 3. táblázatban, amelyben minden mutatóérték egy olyan skálán foglal helyet, amelyen a 100 százalék az adott mutató maximális értéke, negatív értékek pedig negatív adózás előtti eredmény vagy saját tőke esetén fordulhatnak elő.

A ROE-mutató (return on equity - sajáttőke-arányos eredmény) kiszámításához a nemzetközi összehasonlíthatóság érdekében - a szintén használatos adózott eredmény helyett - adózás előtti eredményt használtuk. Ezzel kiszürhető az adórendszerek eltéréséből származó különbség. A torzítások elkerülése végett nem vettük figyelembe azokat az éveket, amikor az adózás elötti eredmény és a saját tőke egyszerre volt negatív az adott megye vállalkozásainak aggregált adatai szerint. Ekkor ugyanis pozitív ROE-értéket kaptunk volna. Ilyen számítási probléma csupán Csongrád megye esetében fordult elő (két évben), és a többi mutatót nem érintette, mivel a felhasznált alapmutatókból csak az adózás előtti eredmény és a saját tőke esetében jegyeztek fel negatív értékeket. Csongrád megye rossz tökehatékonysági mutatója (a 3. táblázat -345 százalékos értéke) is a negatív saját tőkével függött össze.

A mutatók szerint kapott értékek szórása jelentősen eltért: a tőkehatékonyság esetében volt a legnagyobb (89\%) Csongrád megye kiugró értéke miatt, legkisebb pedig $(16 \%)$ az eladósodottság foka mutatónál.

A 3. táblázat adatait felhasználva a vagyoni és pénzügyi helyzet, a jövedelmezöség és a hatékonyság vizsgálatára alkalmazott 4-4 mutatóból átlagszámítással 3 mutatócsoportot képeztünk. Az így kapott értékeket a 4. táblázatban foglaltuk össze. 
A gyümölcs-, zöldségfeldolgozás, -tartósitás alágazat kiválasztott számviteli mutatóinak az adott mutató maximális értékéhez viszonyitott arányai területi egységek szerint, 2008 és 2015 közötti évek átlaga (százalék)

\begin{tabular}{|c|c|c|c|c|c|c|c|c|c|c|c|c|}
\hline Megye, föváros & 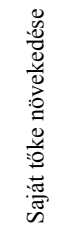 & 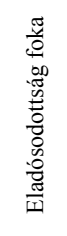 & 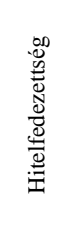 & 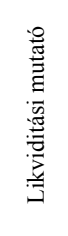 & $\begin{array}{l}\text { 닝 } \\
\simeq\end{array}$ & 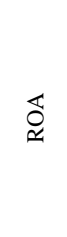 & $\tilde{o}$ & 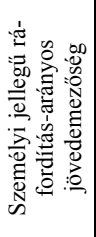 & 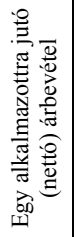 & 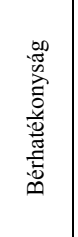 & 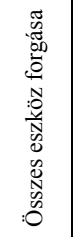 & 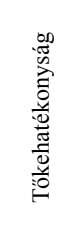 \\
\hline Bács-Kiskun & 19,7 & 61,3 & 41,8 & 41,5 & 0,4 & 1,1 & 0,7 & 1,7 & 45,0 & 61,9 & 55,7 & 32,5 \\
\hline Baranya & 5,3 & 61,6 & 14,2 & 42,9 & $-4,2$ & $-4,3$ & $-3,0$ & $-8,3$ & 45,1 & 71,1 & 51,0 & 86,9 \\
\hline Békés & 9,7 & 62,7 & 17,9 & 30,9 & 1,0 & 2,4 & 2,7 & 3,2 & 21,9 & 31,5 & 33,0 & 22,8 \\
\hline Borsod-Abaúj-Zemplén & 10,0 & 69,6 & 20,4 & 18,9 & 0,0 & 0,0 & $-0,1$ & $-0,1$ & 16,6 & 36,7 & 17,4 & 19,1 \\
\hline Budapest & 7,8 & 65,1 & 67,6 & 40,9 & 3,4 & 8,0 & 5,2 & 11,8 & 25,9 & 58,9 & 55,4 & 40,7 \\
\hline Csongrád & $-0,5$ & 100,0 & 21,2 & 21,1 & 87,4 & $-26,4$ & $-16,9$ & $-28,4$ & 23,4 & 46,4 & 59,9 & $-344,7$ \\
\hline Fejér & 7,4 & 67,5 & 28,1 & 31,8 & $-5,0$ & $-13,3$ & $-9,6$ & $-13,1$ & 25,7 & 35,5 & 50,1 & 32,9 \\
\hline Győr-Moson-Sopron & 30,7 & 47,9 & 100,0 & 67,3 & $-1,3$ & $-3,7$ & $-4,1$ & $-7,6$ & 30,8 & 46,2 & 31,3 & 18,5 \\
\hline Hajdú-Bihar & 9,3 & 75,3 & 27,8 & 35,2 & $-0,4$ & $-0,7$ & $-0,6$ & $-1,0$ & 33,5 & 47,7 & 44,2 & 40,1 \\
\hline Heves & 25,4 & 83,0 & 26,0 & 29,5 & $-3,2$ & $-5,2$ & $-4,5$ & $-7,7$ & 32,9 & 45,5 & 42,3 & 44,8 \\
\hline Jász-Nagykun-Szolnok & 56,4 & 44,8 & 63,3 & 68,8 & 0,1 & 0,3 & 0,3 & 0,6 & 31,2 & 48,0 & 38,0 & 15,9 \\
\hline Komárom-Esztergom & 18,4 & 73,1 & 68,5 & 33,2 & 3,9 & 8,7 & 3,5 & 9,0 & 30,1 & 67,5 & 91,3 & 71,0 \\
\hline Nógrád & 8,9 & 57,0 & 37,7 & 33,2 & 0,2 & 0,7 & 0,4 & 0,7 & 38,2 & 44,9 & 63,4 & 37,4 \\
\hline Pest & 10,0 & 58,7 & 36,1 & 49,5 & 0,8 & 2,0 & 1,1 & 3,1 & 47,4 & 70,3 & 62,8 & 43,8 \\
\hline Somogy & 4,1 & 64,0 & 47,8 & 32,9 & 3,2 & 5,6 & 2,0 & 7,8 & 100,0 & 100,0 & 100,0 & 100,0 \\
\hline Szabolcs-Szatmár-Bereg & 11,2 & 64,1 & 26,4 & 40,3 & 2,5 & 6,2 & 3,2 & 13,7 & 37,5 & 63,9 & 40,4 & 28,5 \\
\hline Tolna & 18,8 & 54,2 & 26,9 & 19,2 & $-12,7$ & $-29,3$ & $-47,3$ & $-40,8$ & 6,5 & 19,2 & 19,2 & 14,5 \\
\hline Vas & 2,0 & 65,0 & 61,7 & 35,9 & 4,3 & 8,8 & 11,5 & 13,1 & 11,4 & 27,7 & 26,0 & 21,8 \\
\hline Veszprém & 1,4 & 87,6 & 23,6 & 35,9 & 100,0 & 100,0 & 100,0 & 100,0 & 8,3 & 26,2 & 36,4 & 63,3 \\
\hline Zala & 100,0 & 24,8 & 68,3 & 100,0 & $-1,3$ & $-7,2$ & $-4,7$ & $-8,7$ & 26,0 & 48,9 & 56,4 & 17,6 \\
\hline Magyarország & 11,3 & 63,8 & 34,4 & 41,1 & 0,4 & 1,1 & 0,7 & 1,7 & 38,5 & 58,2 & 50,4 & 35,7 \\
\hline
\end{tabular}

Megjegyzés. ROE (return on equity): sajáttőke-arányos eredmény; ROA (return on assets): eszközarányos eredmény; ROS (return on sales): árbevétel-arányos eredmény.

A mutatócsoportok képzésénél figyelembe kell venni a multikollinearitás jelenségét is. A multikollinearitás a felállított mutatócsoportokon belül elkerülhetetlen, viszont a csoportátlagok már kevésbé korrelálnak egymással. „A súlyozatlan átlag mintegy „bezárja” az erős területi egység előnyét az altényezőbe.” (Szilágyi [2008] 11. old.) 
A 4. táblázatban a számviteli mutatócsoportok 2008 és 2015 közötti évek átlagára, területi egységenként kiszámított értékeit és a megyék, illetve a föváros azok szerinti sorrendjét foglaltuk össze, dőlt betűkkel kiemelve a legnagyobb termelési értéket előállító Bács-Kiskun, Hajdú-Bihar, Pest és Szabolcs-Szatmár-Bereg megyéket.

4. táblázat

A gyümölcs-, zöldségfeldolgozás, -tartósítás alágazat mutatócsoportjainak értékei* területi egységek szerint és a megyék, illetve a föváros mutatócsoportok szerinti sorrendje, 2008 és 2015 közötti évek átlaga

\begin{tabular}{|c|c|c|c|c|c|c|c|c|}
\hline \multirow{3}{*}{ Megye, föváros } & \multicolumn{2}{|c|}{$\begin{array}{c}\text { Vagyoni és pénzügyi } \\
\text { helyzetet }\end{array}$} & \multicolumn{2}{|c|}{ Jövedelmezőséget } & \multicolumn{2}{|c|}{ Hatékonyságot } & \multirow{2}{*}{\multicolumn{2}{|c|}{ Komplex mutató }} \\
\hline & \multicolumn{6}{|c|}{ vizsgáló mutatócsoport } & & \\
\hline & átlaga $(\%)$ & sorrendje & átlaga $(\%)$ & sorrendje & átlaga $(\%)$ & sorrendje & átlaga $(\%)$ & sorrendje \\
\hline Bács-Kiskun & 41,1 & 7. & 1,0 & 10. & 48,8 & 5. & 30,3 & 8. \\
\hline Baranya & 31,0 & 17. & $-5,0$ & 16. & 63,5 & 3. & 29,9 & 9. \\
\hline Békés & 30,3 & 18. & 2,3 & 8. & 27,3 & 16. & 20,0 & 16. \\
\hline Borsod-Abaúj-Zemplén & 29,7 & 20. & $-0,1$ & 13. & 22,4 & 17. & 17,4 & 18. \\
\hline Budapest & 45,3 & 5. & 7,1 & 3. & 45,3 & 7. & 32,6 & 5. \\
\hline Csongrád & 35,4 & 14. & 3,9 & 7. & $-53,7$ & 20. & $-4,8$ & 20. \\
\hline Fejér & 33,7 & 16. & $-10,3$ & 19. & 36,0 & 12. & 19,8 & 17. \\
\hline Győr-Moson-Sopron & 61,5 & 2. & $-4,2$ & 15. & 31,7 & 15. & 29,7 & 10. \\
\hline Hajdú-Bihar & 36,9 & 12. & $-0,7$ & 14. & 41,4 & 10. & 25,9 & 13. \\
\hline Heves & 41,0 & 8. & $-5,1$ & 17. & 41,4 & 9. & 25,8 & 14. \\
\hline Jász-Nagykun-Szolnok & 58,3 & 3. & 0,3 & 12. & 33,3 & 14. & 30,6 & 7. \\
\hline Komárom-Esztergom & 48,3 & 4. & 6,3 & 5. & 65,0 & 2. & 39,9 & 3. \\
\hline Nógrád & 34,2 & 15. & 0,5 & 11. & 46,0 & 6. & 26,9 & 12. \\
\hline Pest & 38,6 & 9. & 1,7 & 9. & 56,1 & 4. & 32,1 & 6. \\
\hline Somogy & 37,2 & 10. & 4,7 & 6. & 100,0 & 1. & 47,3 & 2. \\
\hline Szabolcs-Szatmár-Bereg & 35,5 & 13. & 6,4 & 4. & 42,6 & 8. & 28,2 & 11. \\
\hline Tolna & 29,8 & 19. & $-32,5$ & 20. & 14,9 & 19. & 4,0 & 19. \\
\hline Vas & 41,1 & 6. & 9,4 & 2. & 21,7 & 18. & 24,1 & 15. \\
\hline Veszprém & 37,1 & 11. & 100,0 & 1. & 33,5 & 13. & 56,9 & 1. \\
\hline Zala & 73,3 & 1. & $-5,5$ & 18. & 37,2 & 11. & 35,0 & 4. \\
\hline Magyarország & 37,6 & - & 1,0 & - & 45,7 & - & 28,1 & - \\
\hline
\end{tabular}

* A mutatócsoport elemeinek maximális mutatóértékéhez viszonyított arányainak számtani átlaga.

A 4. táblázat értékeit jelenítettük meg a 2. ábrán, amelyen látható, hogy a hatékonyság esetében elnyújtottabb a mezőny, a jövedelmezőségnél viszont koncentráltabb, vagyis kisebbek a különbségek. A legnagyobb szórást $(28,5 \%)$ a hatékonyságot mérö mutatócsoportnál tapasztaltuk, a legkisebbet $(11,5 \%)$ pedig a vagyoni és pénzügyi helyzetet vizsgálóknál a jövedelmezőséget mérö mutatócsoport szórása 24 százalék. 
2. ábra. A gyümölcs-, zöldségfeldolgozás, -tartósitás alágazat mutatócsoportjainak értékei területi egységek szerint, 2008 és 2015 közötti évek átlaga

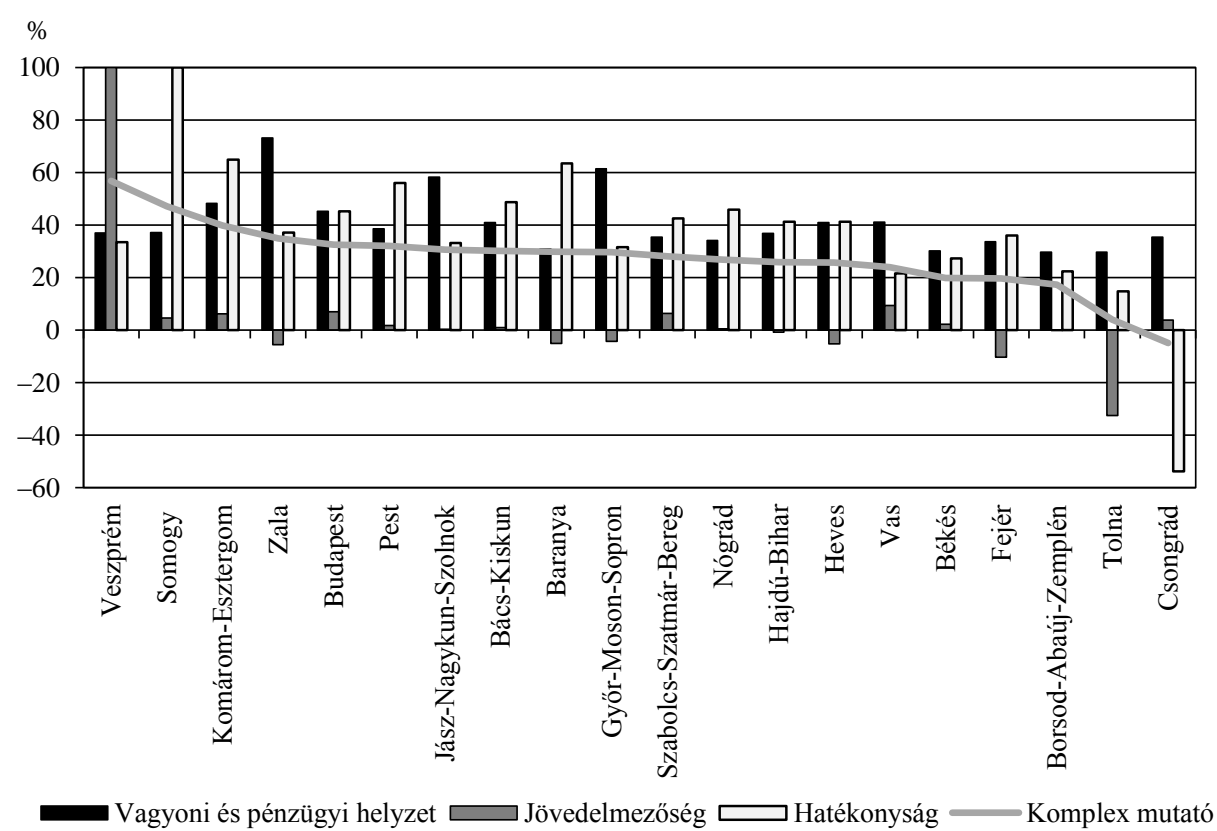

A számítás menetének utolsó lépéseként a három mutatócsoport értékeinek területi egységenként vett számtani átlagaival jutottunk el egy komplex mutatóhoz (a 4. táblázat utolsó előtti oszlopa), amely megítélésünk szerint a vállalkozások vagyoni és pénzügyi helyzetét, jövedelmezőségét és hatékonyságát együttesen jellemezve, a versenyképesség számszerüsített értékeként elfogadható. A 2. ábra a komplex mutató szerint sorba rendezve ábrázolja a vizsgált területi egységeket. A komplex mutató alapján a legjobb helyzetben Veszprém, a legrosszabban pedig Csongrád megye volt a 2008 és 2015 közötti évek átlaga szerint.

Ugyan a versenyképességet mérő módszerek „egységes elfogadásáról nem beszélhetünk" (Molnár [2006] 22. old.), hiszen nincs minden tényezőt figyelembe vevő módszer és mindent egyszerre mérő mutató, azonban a felállított és alkalmazott mutatórendszer mégis számos hasznos információval szolgál a vizsgált területeken.

Az eredmények alapján kijelenthető, hogy a kiszámított komplex mutató is a szakirodalom azon állítását támasztotta alá (Tóth [2005]), amely szerint nem feltétlenül a legnagyobb termelési értéket előállító vállalkozások, illetve területi egységek (Pest, Szabolcs-Szatmár-Bereg, Bács-Kiskun és Hajdú-Bihar megye) vannak a legjobb vagyoni és pénzügyi helyzetben, a leginkább jövedelmezök és hatékonyak, valamint mindezek szintéziseként a legversenyképesebbek. Hiszen kis termelési 
értéket előállító területi egység áll a megállapított rangsor élén minden kiszámított számviteli mutatócsoport és a komplex mutató esetében is. Ennek okait további vizsgálatok hivatottak feltárni.

Mindebböl természetesen nem juthatunk arra a következtetésre, hogy az ország kiváló természeti adottságú és jelentős termelési tapasztalatokkal rendelkező területeivel szemben más megyéket kellene a fejlesztési forrásokkal támogatni. Sokkal inkább arra hívja fel a figyelmet, hogy a tradicionális gyümölcs- és zöldségfeldolgozó területek mellett a kisebb termelési potenciállal rendelkezők számára is számos lehetőség adódik.

„A minél nagyobb profitra törekvő vállalkozások, az üzleti racionalitás elvét követve, befektetési döntéseikben azt mérlegelik, hogy a hasonló kockázatú lehetőségek közül hol realizálhatják a magasabb fajlagos tőkehozamot." (Cseh [2013] 288. old.) A gyümölcs- és zöldségfeldolgozásban érdekelt mezőgazdasági termelőknek és vállalkozóknak, valamint a döntéshozóknak és területfejlesztési szakembereknek együtt kell meggyőzniük a beruházókat arról, hogy az élelmiszeripar jelentős eszközigénye és „az átlagosnál alacsonyabb fajlagos tőkehozama” (Cseh [2013] 302. old.) ellenére érdemes a területen befektetni.

Mindezeken túl az SBS-adatbázis nyújtotta további lehetőségekre is szeretnénk a tanulmányban rámutatni. A lekérdezett adatok segítségével a megyei szintnél is kisebb területi egységek (járások, sőt települések) vállalkozásainak, és ezek gazdálkodásának elemzésére is módunk nyílik. Ebbe enged betekintést a következő három ábra, amelyek az egy alkalmazottra jutó bruttó hozzáadott értéket ábrázolják a gyümölcs-, zöldségfeldolgozás, -tartósítás alágazatba tartozó három szakágazat vállalkozásainak, járási szinten aggregált, a 2015. évre vonatkozó adatait felhasználva. Itt hangsúlyozni kell, hogy a tanulmányban használt bruttó hozzáadott érték a KSH teljesítménystatisztikai módszertanának tényezőköltségen vett bruttó hozzáadott érték fogalma, amely nem egyezik meg a nemzeti számlák bruttó hozzáadott érték fogalmával. Vizsgálatainkhoz számos egyéb mutatót is választhatnánk, de megítélésünk szerint ez az egyik legalkalmasabb a termelékenység mérésére.

A 3. ábra Magyarország burgonyafeldolgozás, -tartósitás szakágazatának 2015ben mért termelékenységét mutatja járásonként. A szakágazatba tartozó vállalkozások 2015 folyamán 0,3 és 8,9 millió forint közötti bruttó hozzáadott értéket állítottak elö alkalmazottanként. A legmagasabb termelékenységet Budapest VI. kerületében, valamint a Budakeszi és a Debreceni járásban múködő vállalkozások érték el. Az említett kerületen és két járáson kívül a Nyíregyházi és a Vecsési járásban, továbbá Budapest XIV. kerületében rendelkeztek székhellyel a szakágazatba tartozó vállalkozások. 


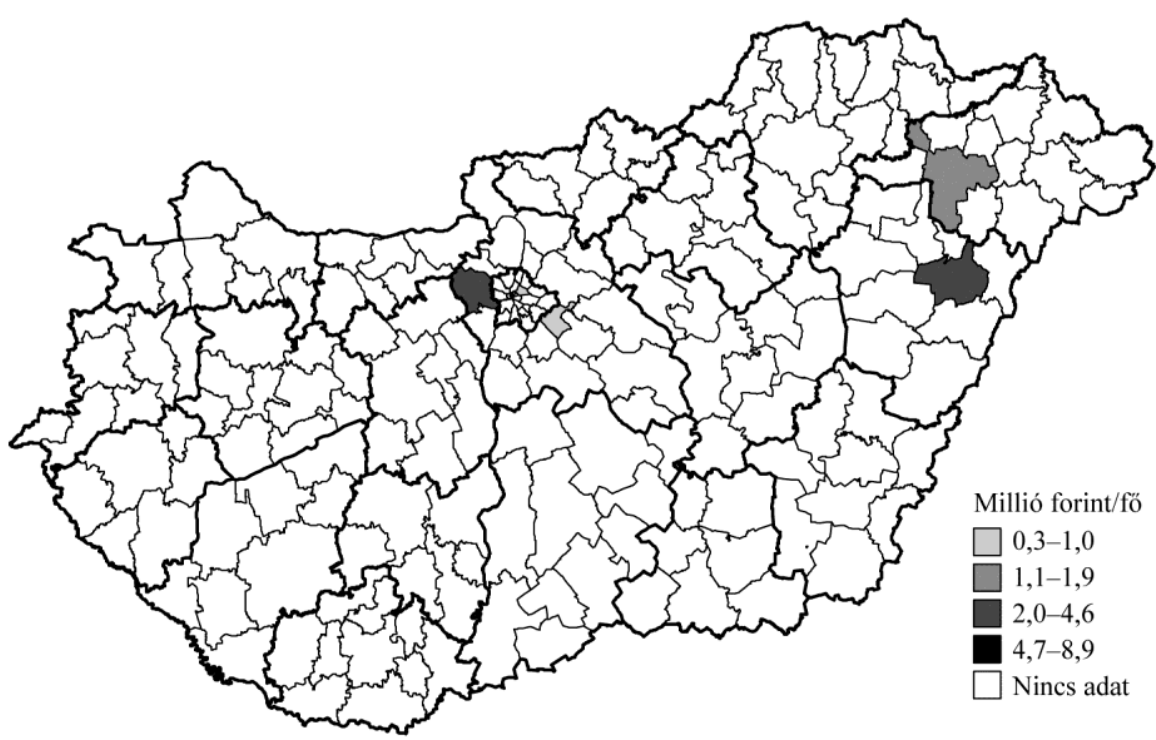

A gyümölcs-, zöldséglé gyártása szakágazat 2015-ben mért, egy alkalmazottra jutó bruttó hozzáadott értéke jelenik meg a 4. ábrán járásonként.

4. ábra. A gyümölcs-, zöldséglé gyártása szakágazat termelékenysége járásonként, 2015 (Bruttó hozzáadott érték/alkalmazott)

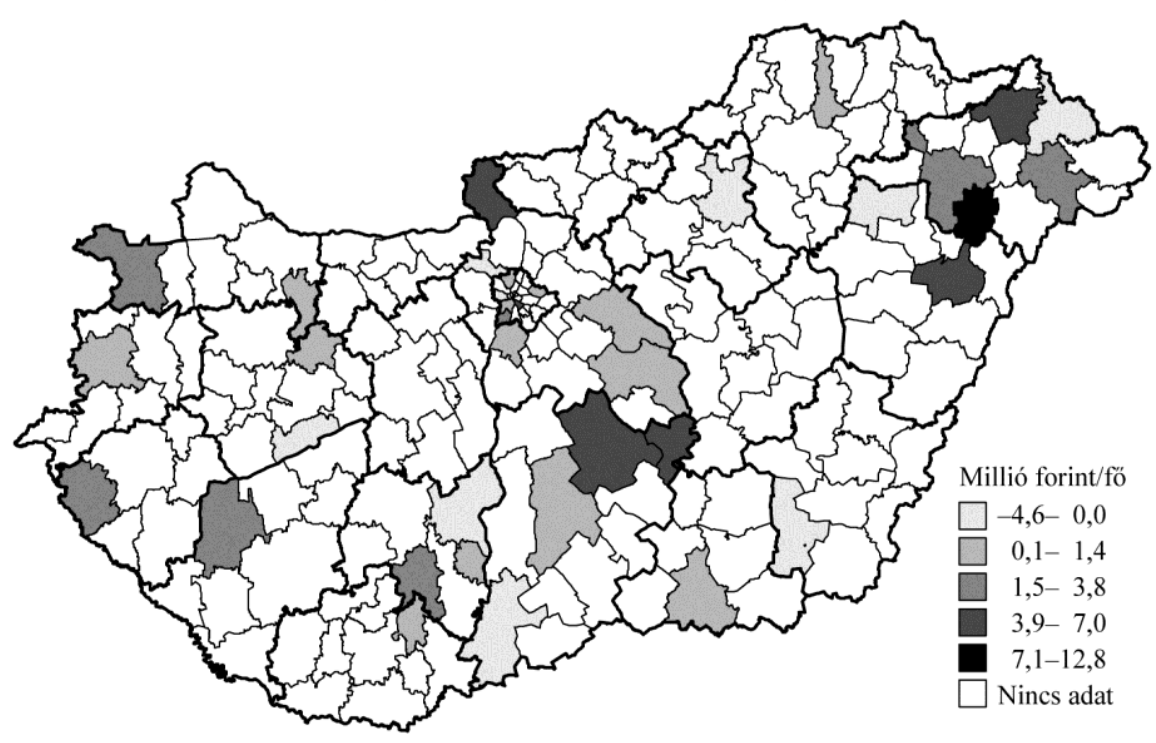


A szakágazatban a legnagyobb termelékenységet a Nagykállói járás vállalkozásai érték el. Öket a Kecskeméti, a Szobi, illetve a Tiszakécskei járások követték 5,7 és 7 millió forint közötti összeggel.

Habár a Sió-Eckes Kft. az ország egyik legnagyobb gyümölcslégyártója, de statisztikai fötevékenysége szerint nem a gyümölcs-, zöldséglé gyártása szakágazatba tartozott 2015-ben, ezért nem jelenítettünk meg adatot a 4. ábrán a Siófoki járásra vonatkozóan.

5. ábra. Az egyéb gyümölcs-, zöldségfeldolgozás, -tartósitás szakágazat termelékenysége járásonként, 2015 (Bruttó hozzáadott érték/alkalmazott)

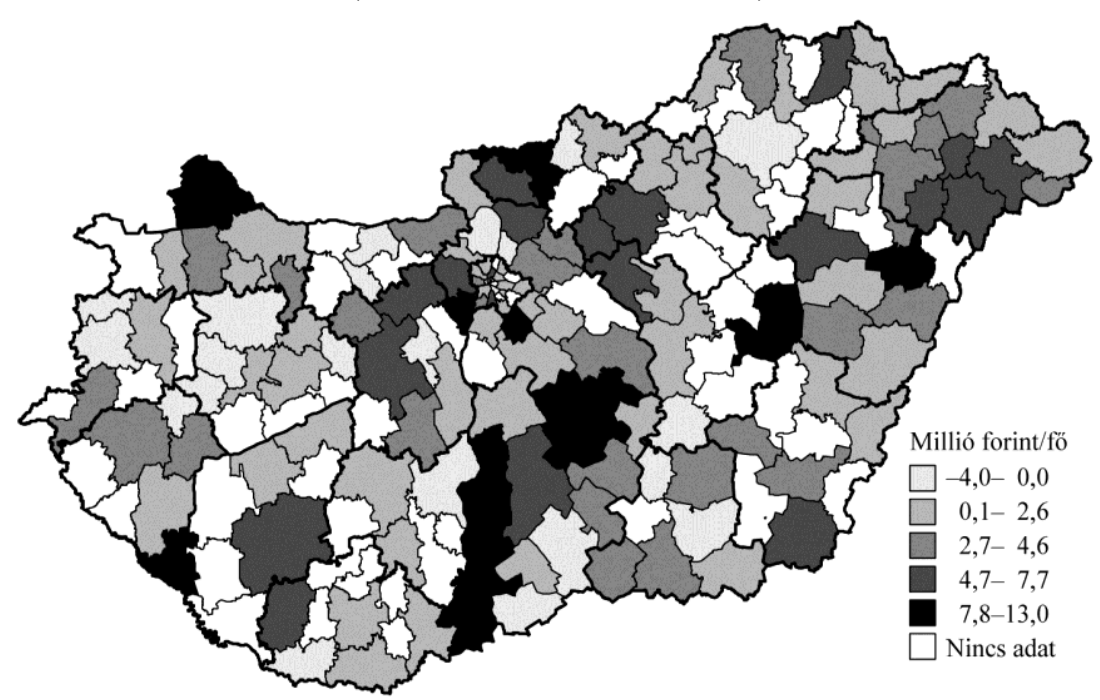

Az 5. ábrán az egyéb gyümölcs-, zöldségfeldolgozás, -tartósitás szakágazat 2015ben mért termelékenysége látható járásonként. Az ebben a szakágazatban müködő vállalkozások száma jóval nagyobb az előző kettőnél, és a járások több, mint felében müködött ilyen tevékenységet végző vállalkozás.

\section{4. Összefoglalás}

A tanulmányban a gyümölcs-, zöldségfeldolgozás, -tartósítás alágazat megyénkénti teljesítményét értékeltük a vállalkozások vagyoni és pénzügyi, jövedelmezőségi, valamint hatékonysági helyzetét mérő számviteli mutatószámok segítségével, a 2008 és 2015 közötti évek adatait felhasználva. Vizsgálataink során a hivatkozott 
szakirodalmi megközelítések és fogalmi meghatározások azon közös vonásából indultunk ki, amely a termelékenységet helyezi a versenyképesség fókuszába.

Az eredmények alapján kijelenthető, hogy a kiszámított mutatók a szakirodalom azon állítását támasztották alá (Tóth [2005]), amely szerint nem feltétlenül a legnagyobb termelési értéket előállító vállalkozások, illetve területi egységek (Pest, Szabolcs-Szatmár-Bereg, Bács-Kiskun és Hajdú-Bihar megye) vannak a legjobb vagyoni és pénzügyi helyzetben, a leginkább jövedelmezök és hatékonyak, valamint mindezek szintéziseként a legversenyképesebbek. Hiszen kis termelési értéket elóállító területi egység áll a rangsor élén minden kiszámított számviteli mutatócsoport és a komplex mutató esetében is. Ennek okait további vizsgálatok hivatottak feltárni.

Mindez azonban nem jelentheti, hogy az ország kiváló természeti adottságú és jelentős termelési tapasztalatokkal rendelkező területeivel szemben más megyéket kellene a fejlesztés fókuszába állítani. Sokkal inkább a tradicionális gyümölcs- és zöldségfeldolgozó vidékek mellett a kisebb termelési potenciállal rendelkező területekben rejlő lehetőségekre hívja fel a figyelmet.

A kapott eredmények alapján kijelenthetjük, hogy az SBS-adatbázis megbízható forrása a versenyképességi számításoknak, és sok mutató kiszámítására biztosít lehetőséget. Az általunk kiválasztott számviteli mutatók pedig olyan sorrendeket állítottak fel a megyék és Budapest gyümölcs-, zöldségfeldolgozás, -tartósítás alágazatba tartozó vállalkozásainak vagyoni és pénzügyi helyzetére, jövedelmezöségére, hatékonyságára és versenyképességére vonatkozóan, amelyek alkalmasak a vállalati döntéstámogatás mellett területfejlesztési stratégiák kialakítására és formálására is.

\section{Függelék}

\section{Vagyoni és pénzügyi helyzetet vizsgáló mutatók}

- Saját tőke növekedési mutató: $\frac{\text { Saját tőke }}{\text { Jegyzett tőke }}$.

- Eladósodottság foka: $\frac{\text { Kötelezettségek }}{\text { Összes eszköz }}$.

- Hitelfedezettség mutató: $\frac{\text { Követelések }}{\text { Rövid lejáratú kötelezettségek }}$.

- Likviditási ráta: $\frac{\text { Forgóeszközök }}{\text { Rövid lejáratú kötelezettségek }}$.

\section{Jövedelmezőségi mutatók ${ }^{2}$}

- ROE (return on equity - sajáttőke-arányos eredmény): $\frac{\text { Adózás előtti eredmény }}{\text { Saját tőke }}$.

${ }^{2}$ A jövedelmezőségi mutatók kiszámításához az eltérő nemzeti adórendszerekből fakadó különbségek kiküszöbölése, a nemzetközi összehasonlíthatóság érdekében az adózás előtti eredményt használtuk. 
- ROA (return on assets - eszközarányos eredmény): $\frac{\text { Adózás előtti eredmény }}{\text { Összes eszköz }}$.

- ROS (return on sales - árbevétel-arányos eredmény): $\frac{\text { Adózás előtti eredmény }}{\text { Összes bevétel }}$.

- Személyi jellegủ ráfordítás-arányos eredmény: $\frac{\text { Adózás előtti eredmény }}{\text { Személyi jellegủ ráfordítások }}$.

\section{Hatékonysági mutatók}

- Egy alkalmazottra jutó (nettó) árbevétel: $\frac{\text { Értékesítés(nettó) árbevétele }}{\text { Alkalmazottak száma }}$.

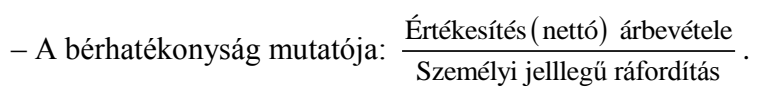

- Az összes eszköz forgása: $\frac{\text { Értékesítés(nettó) árbevétele }}{\text { Összes eszköz }}$.

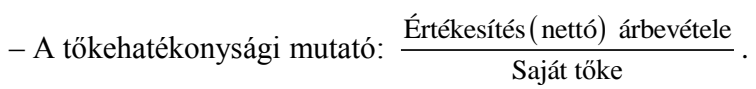

\section{Irodalom}

CHIKÁn A. [2006]: A vállalati versenyképesség mérése. Pénzügyi Szemle. 51. évf. 1. sz. 42-56. old.

Cox, A. [1997]: Business Success: A Way of Thinking about Strategy, Critical Supply Chain Assets and Operational Best Practice. Earlsgate Press. Boston.

CZAKÓ E. - CHIKÁN A. [2007]: Gazdasági versenyképességünk vállalati nézőpontból, 2004-2006. Vezetéstudomány. 38. évf. 5. sz. 2-8. old.

CSEH T. [2013]: Fajlagos ágazati tőkehozamok a magyar gazdaságban 1995 és 2009 között. Statisztikai Szemle. 91. évf. 3. sz. 287-305. old.

EuRÓPAi BIZOTTSÁG [2014]: Befektetés a munkahelyekbe és a növekedésbe. A fejlödés és a felelösségteljes kormányzás elösegitése az EU régióiban és városaiban. Hatodik jelentés a gazdasági, társadalmi és területi kohézióról. Brüsszel.

FINDRIK M. - SzILÁRD I. [2000]: Nemzetközi versenyképesség - képességek versenye. Kossuth Kiadó. Budapest.

Harsányi G. - Siklósi Á. - Veress A. [2013]: Értékelés a számvitelben. Számvitel Adó Könyvvizsgálat: SZAK-ma. 12. évf. 4. sz. 558-559. old.

HÜTTL A. [2012]: Termelékenység a magyar gazdaságban. Versenyképesség kutatások mühelytanulmány-sorozat. TM 63. sz. Budapesti Corvinus Egyetem. Budapest.

IMD (International Institute for Management Development) [2008]: IMD World Competitiveness Yearbook 2008. Lausanne.

KADLECSIK R. [2013]: A feldolgozóipari vállalkozások elemzése jövedelmezőségi és hatékonysági mutatók alapján. Statisztikai Szemle. 91. évf. 11. sz. 1072-1091. old.

Krugman, P. [1996]: Pop Internationalism. MIT Press. Cambridge.

MNB (MAGYAR NEMZETI BANK) [2017]: Versenyképességi jelentés, 2017. Budapest

MoLnÁR A. [2006]: Versenyképesség és -stratégiák a magyar élelmiszeriparban az uniós csatlakozás tükrében. Akadémiai Kiadó. Budapest. 
MóDos GY. [2004]: A versenyképesség összetevői és mérési módszerei a hús-termékpályán. Agroinform Kiadó. Budapest.

NÉMETHNÉ GÁL A. [2009]: A kis- és középvállalatok versenyképessége. PhD-értekezés. Széchenyi István Egyetem. Győr.

NÉMETHNÉ GÁL A. [2010]: A kis- és középvállalatok versenyképessége - egy lehetséges elemzési keretrendszer. Közgazdasági Szemle. LVII. évf. Február. 181-193. old.

PORTER, M. E. [1980]: Competitive Strategy. Techniques for Analyzing Industries and Competitors. The Free Press. New York.

Porter, M. E. [1990]: The Competitive Advantage of Nations. The Free Press. New York.

SZILÁGYI Gy. [2008]: A versenyképesség mérése a nemzetközi összehasonlítások módszertanának tükrében. Statisztikai Szemle. 86. évf. 1. sz. 5-21. old.

Tóтн J. [2005]: Müködési versenyképesség és hajtóerői a hazai húsiparban. Közgazdasági Szemle. LII. évf. Július-augusztus. 743-762. old.

Traill, W. B. - PITTS, E. [1998]: Competitiveness in the Food Industry. International Thomson Publishing. London.

\section{Summary}

The authors create a ranking of Hungary's territorial units by their competitiveness in fruit and vegetable processing by means of accounting. The aim of the paper is to examine whether the territorial units having higher production value in fruit and vegetable processing are in a better financial and wealth position and whether they are more profitable, more efficient and therefore more competitive than their counterparts.

The study seeks to demonstrate the multiple usability of the SBS (structural business statistics) database that is a reliable source of competitiveness calculations. The ranking is suitable not only for supporting business decisions but also for developing territorial development strategies. 